\title{
E-Commerce Gamification: The Effect of gameful Experience (Gamex) and Game Design on The Self-brand Connection
}

\author{
Ika Diyah Candra Arifah*
}

\author{
${ }^{\prime}$ Student of Doctoral Program, Technology Management Department, Institut Teknologi Sepuluh November. \\ ${ }^{2}$ Department of Management, Faculty Economics and Business, Universitas Negeri Surabaya \\ *Corresponding author.Email: ikaarifah@unesa.ac.id
}

\begin{abstract}
The potential of e-commerce is vast in supporting consumption-driven Indonesian economics. E-commerce has also become the leading marketing platform for SMEs during the Covid-19 pandemic. Although supported by growing and dynamic e-commerce start-up ecosystem, Indonesian e-commerce still has several weaknesses in retaining their loyal consumers, such as less effective and innovative banner blindness due to consumer avoidance of e-commerce advertisements. In the other side, unique value proposition is needed when Indonesian e-commerce market gets saturated due to fierce competition and low barrier for new competitors. Hence, an effective marketing strategy is essential to increase brand engagement of e-commerce consumers with gamification. This study aims to examine the effect of gameful experience (GAMEX) and game design of e-commerce advergames on self-brand connections that motivate purchases, which were previously studied separately by researchers. By including the brand engagement variable as a mediation on this effect, this study also examine the emotional and cognitive engagement on self-brand connections resulted by experiential marketing. This experimental study employed quantitative approach to 250 frequent e-commerce users. The results shows a positive and significant effect of gameful experience and game design elements on self-brand connection mediated by brand engagement. This study is expected to make a practical contribution to ecommerce marketers and UX designers, identify and recommend experimental qualities in e-commerce advergame design to engage loyal customers which influence their purchasing intention that directly supports the business sustainability of SMEs in e-commerce platform.
\end{abstract}

Keywords: E-Commerce, Gamification, Advergame, Gameful Experience, Game Design, Self-Brand Connection.

\section{INTRODUCTION}

The market capitalization of e-commerce in Indonesia is USD 20 billion and becomes the seventh largest in the world and the largest in Southeast Asia [1]. Although it is still in the early stages of digitization due to uneven ICT infrastructure, transactions through e-commerce have reached $30 \%$ of total country transactions in Indonesia. This trend is supported by the dynamic growth of the e-commerce start-up ecosystem, which has a positive impact on the national economy by providing 26 million employees in the Small and Medium Enterprise sector.

This rapid growth has also encouraged foreign direct investment into Indonesia, amounting to USD 3 billion in 2015-2017, which entered several Indonesian e-commerce sites such as Bukalapak, Matahari Mall and Tokopedia. A digital savvy millennial makes up $65 \%$ of today's "mobile-first" e-commerce shoppers. This growth also impacts increasing export volume by USD 22 million, especially in fashion, automotive, health/beauty and jewelry products [1].

Commerce is having a large impact on the national economy. Therefore, industry participants have a great deal of pressure to improve productivity and to extend access to the workforce for all parts of the population. To succeed in the new digital era, businesses in the e-commerce industry must adapt to the challenge and overhaul their business model so that they can lead in national and global market share. The five imperative strategies to spearhead growth and efficiency are: (1) delivering a consumer-centric experience for a seamless e-commerce proposition with competitors, ( 2 with big data for real-time decisions across the value chain, (3) boosting cyber security to protect corporate information capital in a connected world, and (4) utilizing omnichannel engagement to tie in online and offline activities [2].

Therefore, innovation and value-added are expected to be created in the dimensions of products/services, business models and business processes [3] [4]. By applying game design concepts to non-game contexts, such as businesses, we can better define the phenomenon of gamification [4] [5].

Furthermore, gamification can be useful in increasing sales and enhancing corporate image. Most of the research shows that gamification is an effective marketing tool to raise consumer brand or product awareness. Gamification has a positive effect on brand association and brand trust [6]; brand engagement [7], consumer attitudes [8] [9]; consumer's innovation adoption [10]; customer loyalty [11] [12]; purchase intention [13] [14]; customer satisfaction [15]; consumer willingness to pay [16]; actual sales [17]. However, research on gameful experience in these studies only examines the dimensions of experience 
[18] and separated from game effectiveness by design [5] [19] [15] [1].

Several studies measure the effect of game design on customer engagement [20] [21] and patronage intention [22], but no one has investigated its effect on self-brand connection in e-commerce. In addition, research that directly relates the gameful experience dimension to consumer behaviour is not sufficient to explain how consumers immersed in gamified products/services or games because they do not include psychological factors such as emotional and cognitive engagement.

Hence, this research aims to determine how gameful experience (GAMEX) and game design affect self-brand connection? Moreover, what is the role of brand engagement mediation in the relationship between a gameful experience (GAMEX) and game design on self-brand connection?

The research is expected to provide a theoretical contribution that describes the interaction and interrelationships between a gameful experience (enjoyment, absorption, creativity, absence of adverse effects, and emotion) and game design (mechanics, aesthetics, story and technology) with the self-brand connection. For e-commerce marketers and UX designers, this study aims to identify and recommend experimental qualities in e-commerce advergame design to support SMEs resilience.

\section{LITERATURE REVIEW}

\subsection{Advergame in E-Commerce}

The game has five characteristics: (1) it is based on rules; (2) it has measurable variable outcomes; (3) different game outcomes are assigned positive and negative values; (4) it takes effort to improve the results; (5) the result is essential for the game-player [24].

Games also be defined experientially [18]. Experience component necessitates a more detailed description for the game to be fully comprehended [23]. This is because the variety of game types provides more than a single experience [5]. The difference is a game can only be distinguished by its various experiences. It emphasizes the multidimensional nature of gaming experience. Hence, the game experience functionates as a mediator between gamified service motivational drive and the expected behavioral outcomes [18] [25].

However, the personalization of incentives affects the gamification process because different people have different motivations [26] [5] [27] [25] [28]. This statement is relevant to previous research, which states that self-brand connection is mediated by intrinsic motivation [31].

Advertising games (advergame) are games that explicitly or completely incorporate promotional content as marketing tools into a game. In advergame, the brand is integrated with the story, mission, and other activities in the game. Advergame effectiveness usually supported by several game elements such as characters with certain brands, gameplay displaying the characteristics of certain products, advertising banners in a game segment, or other elements [32].

Advergames have begun to be glimpsed by several companies to market their products and brands to raise awareness of the brands and products owned by the company [32]; [33]; [35]. Advergames began to appear, motivated by the tendency of consumers to engage in avoidance behaviour toward advertisements through cognitive ways by deliberately ignoring them and reducing their exposure to the ads content [36].

Furthermore, banner blindness posits about ineffective communication element in the online environment because it is unnoticeable by consumers, either intentionally or unintentionally [37]. Due to the overload information, consumers are immersed in activities in the online environment, consumers tend to pay attention to specific points on online information pages that can help them carry out these activities and ignore other points that they consider irrelevant and distractions.

In advertising, one of the essential elements forming attitudes in mobile advertising is entertainment, informativeness, and irritation [38]. The weakness that arises in the form of intrusiveness caused by advertising is consumer perceptions of advertising as harmful because of its certain formats that consumers consider disturbing [39]. This perception of intrusiveness arises because advertisements tend to force consumers to stop all activities they are doing in the online environment. This disturbing situation creates negative emotions or feelings of anger (irritation) consumers [40]. Therefore, attractive, and fun experience provided by advergame can be a solution to introduce new products or maintain consumer engagement with brands and increase sales than pure advertisement [32].

The characteristics of creating a balanced advergame are "making purchases part of the game". By keeping players in the game (allowing players to buy whatever they want in the game, without interrupting the game); unify the player experience (whether players buy on a traditional PC mobile device or in-store, all transactions look integrated across all channels; provide personalized offers (cross-selling, impulse buying promotions, targeted offers and exclusive merchandise, real-world, game-related); and add a buy anywhere button (giving developers the freedom to place a one-click "buy" button anywhere in the game without them having to learn the trading logic) [34].

\subsection{Gameful Experience}

Gamification refers to transforming technology such as games to generate positive experiences and motivations and influence user behaviour [41]. Gaming experience drives behavioural effects on its users [18]; [27]; [28]. As a result, when developing gamified services for e-commerce, the user's experience should be the primary consideration. The GAMEX dimension 
used in this study to measure gameful experience [42]. The following is a description of each element:

1. Fun. It is an important aspect of how people interact with games [43]. People will play if they enjoy the experience [44], so fun is arguably the primary goal of a game.

2. Consumption (flow, immersion, and presence)

a. Flow is a repetitive experience in games [45] [46] [44] that indicated by player's intense attention, shifted sense of moment, and combined awareness and action [47]. A person in a flow state is autotelic; he acts for his own sake rather than for the others' sake [47]. Perceived balance of challenge and skill will occur flow [48].

b. Immersion has been defined as entering an "ingame" cognitive state [49], in which the player has the sensation of being inside another reality that demands full attention and make players feel disconnected from the outside world [50].

c. Presence. Presence is defined as a nonmediation illusion or a feeling of being inside a computer-generated world [53].

3. Creative thinking. These elements represent the game experience's dimensions. Most game researchers consider exploration and imagination to be an important part of the player's playing experience [52].

4. The absence of any negative consequences. Gamified applications should be enjoyable to use and reduce the risk of losing in win-lose situations to avoid negative feeling effects for players [54].

5. Emotions. Emotions have been described as the superordinate program that coordinates behavior for it to be functional (from an evolutionary standpoint) [55]. Emotional states influence experience on a broad level. Hence, the hypothesis of this research is:

H1: Gameful Experience (GAMEX) has a direct impact on the self-brand connection.

\subsection{Game Design}

The Elemental Tetrad Game is a well-known gamedesigning framework. The model is made up of four interconnected design elements that create game's cognitive and affective ecosystems [56].

The first element, the story, gives meaning to the consumption experience. E-commerce companies understand the value of "storytelling" as a strategy of persuade consumers, but not how to effectively use ingame (mobile) story elements for marketing. Narrative transport research sheds light on the value of stories [58].

Storytelling is a "convergent process" [57]. First, the recipient must focus on the story's development and analyze it. Also, two elements contribute to narrative delivery: mental imagery and empathy. Empathy, on the other hand, reflects the recipient's attempt to understand and connect to the characters of game story.
The player becomes "lost" in the story and experiences narrative transport. Besides giving meaning to the player's experience, story also sets the stage for task completion, and guide action [58]. Meanwhile, mechanics set the game's rules, gives information about the game goals and how players achieve it. Leaderboards and badges are common game mechanics. [18]

Additionally, making a game look and feel good is important. Games should instill their players with a sense of purpose, and a storyline should be strengthened. Finally, technology is concerned with how media, specifically mobile platforms in this study, shape game experiences. For example, the ability of mobile devices to function as networked computers allows for dynamic interactivity and gameplay [59].

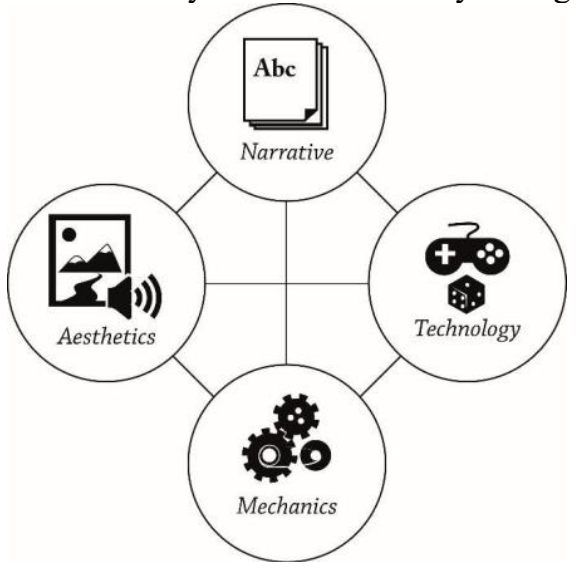

Figure 1 Tetrad Game Design Elements Source: [59]

Hence, the hypothesis of this research is: $\mathrm{H} 2$ : Game design directly affects self-brand connection

\subsection{Brand Engagement}

Brand involvement has been theorized to link consumers' recent experiences with brand connections because previous research has shown that it has the capability to metaphorically conceptualize and link consumers' personal experiences with brand connections [60;61]. Affective and cognitive responses can both be triggered when using flow to perform experiential activities [62]. Refers to previous research, it was discovered that offering more interactive and engaging browsing experiences for customers results in greater website enjoyment [63] and, in turn, more frequent online shopping [64]. Similar research has been done in the context of games. In other words, when players can interact with or feel challenged by the game, they enjoy it more. Further research on the effect of games on brand memory indicates that more interactive relationships with brands lead to increased brand recognition [67]. Furthermore, studies have shown that positive influence and persuading brand 
evaluation [69] [70] leads to a stronger relationship with the brand. This previous study stated that online experiential activity, and branding supports gamification interactions. It is distinguished by high interactivity. Hence, the following are the research hypotheses:

H3: A fun experience has a direct impact on brand engagement.

H4: Game design has a direct impact on brand engagement.

H5: Brand engagement moderates the impact of GAMEX and Game Design on self-brand connection. As a result, the research model is as follows:

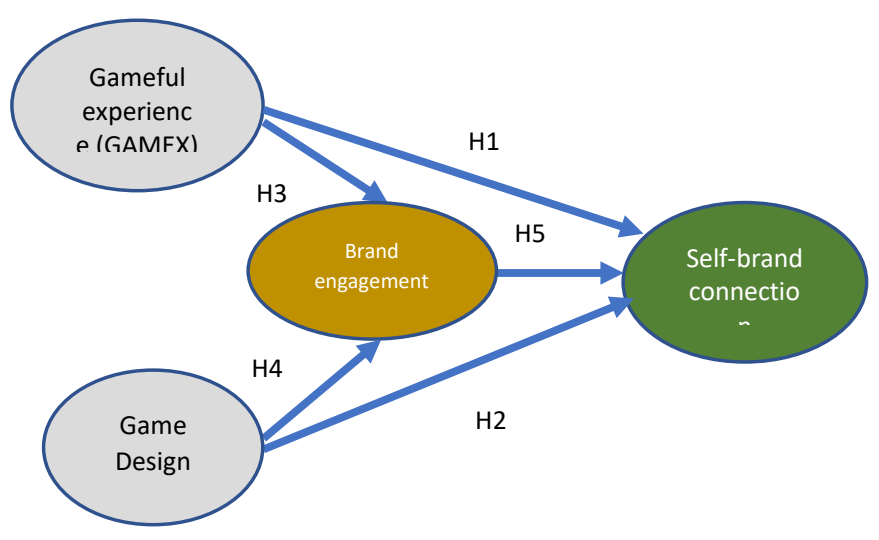

Figure 2 Research Model

\section{RESEARCH METHOD}

This study employs an experimental approach with quantitative measurement. Participants were instructed to complete at least the first four levels of the microgame on Shopee, a video game recommendation selected by the researcher. Returning to the online questionnaire, participants respond to seven-point Likert scaled answer (from "strongly disagree" to "strongly agree") to determine how they felt about the microgame.

Purposive sampling with the criterion of respondents being between the ages of 18 and 50 was used. This demonstrated their propensity to frequent use of ecommerce platforms as proven by their rating as a Silver user in Shopee. 250 samples were taken, and SmartPLS was used to analyse the results. Path analysis explores the relationship between the dependent and independent variables by testing both the inner and outer models and the hypothesis that links them.

\subsection{Outer Model Analysis}

In outer model, the first measurement to be conducted with the PLS-SEM model is the reflective measurement. The measurement model was evaluated by determining the reliability and validity of the results. To obtain high levels of reliability, Cronbach's Alpha can be utilized. This is the model's estimate of how reliable all of the indicators are. Ideally, the minimum value is 0.8 or 0.9 . Composite Reliability is used, and interpreted in the same manner as Cronbach's Alpha.

The variance of each indicator must be attributed to each latent variable by at least $50 \%$. Also, since the latent variables' relationships with their indicators must be greater than 0.7 , the outer loadings must be greater than their absolute value. If the external standard loading is less than 0.4 , the reflective indicator should be omitted from the measurement model.

Both convergent and discriminant validity exist in PLSSEM. When the set of indicators represent one latent variable, and that underlying latent variable, a measure is called convergent validity. This can be shown to be unidimensional by demonstrating the AVE, which is greater than 0.5 . Conceptually different concepts must exhibit sufficient difference to be different concepts. Fornell-Larcker and "cross-loadings" are utilized in discriminant validity. According to the Fornell-Larcker postulate, the latent variable will have a larger contribution to the underlying indicator variable than other latent variables. This conclusion follows from statistical inference, and according to that inference, the AVE of each latent variable must have a value greater than or equal to the highest $r 2$ value with the values of the other latent variables.

\subsection{Inner Model Analysis}

Inner model analysis shows the value of direct effects that represented by path coefficient. Furthermore, path coefficients between constructs was carried out to know the relationship's significance and strength and hypothesis testing. It ranges from -1 to +1 . When the path coefficient value is getting closer to the +1 value, the relationship between the two constructs is positive and strong and conversely for value for -1 is negative relationship [71].

Furthermore, R Square was used to know the goodness-fit-model test in the PLS-SEM inner model. The value of the coefficient of determination ( $R$ Square) is expected to be between 0 and 1. R Square values of $0.75,0.50$, and 0.25 indicate that the model is strong, moderate, and weak [71]. While the Adjusted R Square is the R Square value that has been corrected based on the standard error value. Adjusted R Square value provides a stronger picture than $\mathrm{R}$ Square in assessing the ability of an exogenous construct to explain endogenous constructs.

To analyse the model fit criteria, criteria for the fit model include SRMR or Standardized Root Mean Square $<0.10$ or $<0.08$ and NFI value $>0.9$ [73]

The assumption or requirement in the inner least square model analysis is that there is no multicollinearity problem; namely, there is a strong intercorrelation between latent variables. This study uses the VIF indicator to evaluate collinearity. The VIF value must be less than five [71]. Finally, hypothesis testing uses the Bootstrapping method, with a p-value criterion of less than 0.05 , indicating that the hypothesis is accepted. 


\section{RESULT \& DISCUSSION}

\subsection{Outer Model}

The results of outer loading show several indicators that are less than 0.4 , namely GE7, which discusses the dominance indicator, or feeling automated when playing advergames, GD6 which is an indicator for game testing; and BE3, which discusses pride in using e-commerce brands, so these indicators were excluded in the subsequent analysis of the inner model.

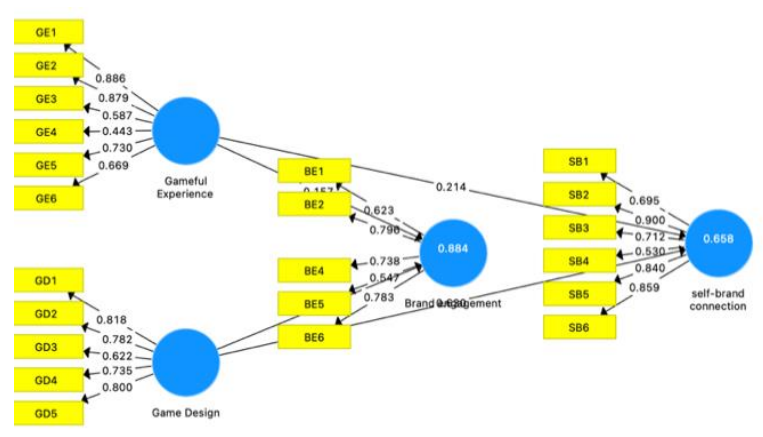

Figure 3. Outer Loading Result

Furthermore, the reliability and validity test of the outer model analysis is shown in Table 1 below:

Table 1 Outer Model Analysis

\begin{tabular}{|c|c|c|c|c|}
\hline & $\begin{array}{l}\text { Cronbach's } \\
\text { Alpha }\end{array}$ & rho_A & $\begin{array}{l}\text { Composite } \\
\text { Reliability }\end{array}$ & $\begin{array}{l}\text { Average } \\
\text { Variance } \\
\text { Extracted } \\
\text { (AVE) }\end{array}$ \\
\hline $\begin{array}{c}\text { Brand } \\
\text { Engagement }\end{array}$ & 0,752 & 0,770 & 0,843 & 0,576 \\
\hline Game Design & 0,870 & 0,885 & 0,905 & 0,658 \\
\hline $\begin{array}{l}\text { Gameful } \\
\text { Experience }\end{array}$ & 0,819 & 0,864 & 0,881 & 0,651 \\
\hline $\begin{array}{l}\text { Self brand } \\
\text { connection }\end{array}$ & 0,866 & 0,883 & 0,905 & 0,661 \\
\hline
\end{tabular}

Table 2 Discriminant Validity Result

\begin{tabular}{|l|l|l|l|l|}
\hline & $\begin{array}{l}\text { Brand } \\
\text { Engagement }\end{array}$ & $\begin{array}{l}\text { Game } \\
\text { Design }\end{array}$ & $\begin{array}{l}\text { Gameful } \\
\text { Experience }\end{array}$ & $\begin{array}{l}\text { Self-brand } \\
\text { connection }\end{array}$ \\
\hline $\begin{array}{l}\text { Brand } \\
\text { Engagement }\end{array}$ & $\mathbf{0 , 7 5 9}$ & & & \\
\hline $\begin{array}{l}\text { Game } \\
\text { Design }\end{array}$ & 0,865 & $\mathbf{0 , 8 1 1}$ & & \\
\hline $\begin{array}{l}\text { Gameful } \\
\text { Experience }\end{array}$ & 0,838 & 0,814 & $\mathbf{0 , 8 0 7}$ & \\
\hline $\begin{array}{l}\text { Self-brand } \\
\text { connection }\end{array}$ & 0,795 & 0,777 & 0,728 & $\mathbf{0 , 8 1 3}$ \\
\hline
\end{tabular}

From these results, it can be seen that all variables have Cronbach's Alpha and composite reliability of all variables above 0.7. This shows that each latent variable in this study can explain the variance of each indicator by at least $50 \%$. The AVE value of each variable also shows a value above 0.5 which indicates the convergent validity of each variable indicator. Furthermore, discriminant validity can be determined using the Fornell-Lecker criteria, as presented in Table 2. The results show a higher value than the AVE value so a latent variable shares more variance with its indicator compared to other latent variables.

\subsection{Inner Model}

Based on the results of the path coefficient, Table 3 below shows a value close to +1 . The highest path coefficient is found in the relationship between gameful experience and self-brand connection with 0.536 , while the lowest direct relationship is in the game design variable to the self-brand connection of 0.313 . Hence, it can be concluded that there is a direct relationship between latent variables.

\section{Table 3 Path Analysis}

\begin{tabular}{|l|l|l|l|l|l|}
\hline & $\begin{array}{l}\text { Path } \\
\text { Coefficient }\end{array}$ & $\begin{array}{l}\text { Sample } \\
\text { Mean } \\
\text { (M) }\end{array}$ & (STDEV) & T Statistics & $\begin{array}{l}\text { P } \\
\text { Values }\end{array}$ \\
\hline $\begin{array}{l}\text { Brand } \\
\text { Engagement -> } \\
\text { Self brand } \\
\text { connection }\end{array}$ & 0,544 & 0,438 & 0,098 & 4,379 & 0,000 \\
\hline $\begin{array}{l}\text { Game Design -> } \\
\text { Brand } \\
\text { Engagement }\end{array}$ & 0,395 & 0,544 & 0,041 & 13,423 & 0,000 \\
\hline $\begin{array}{l}\text { Game Design -> } \\
\text { Self brand } \\
\text { connection }\end{array}$ & 0,313 & 0,309 & 0,085 & 3,689 & 0,000 \\
\hline $\begin{array}{l}\text { Gameful } \\
\text { Experience -> } \\
\text { Brand } \\
\text { Engagement }\end{array}$ & 0,395 & 0,397 & 0,045 & 8,863 & 0,000 \\
\hline $\begin{array}{l}\text { Gameful } \\
\text { Experience -> } \\
\text { Self brand } \\
\text { connection }\end{array}$ & 0,536 & 0,110 & 0,067 & 1,696 & 0,000 \\
\hline
\end{tabular}

Table 4 Goodness of Fit

\begin{tabular}{|l|c|c|}
\hline & Saturated Model & Estimated Model \\
\hline SRMR & 0,090 & 0,076 \\
\hline d_ULS & 2,892 & 2,892 \\
\hline d_G & 4,578 & 4,578 \\
\hline Chi-Square & 3380,703 & 3380,703 \\
\hline NFI & 0,91 & 0,76 \\
\hline
\end{tabular}

Furthermore, the Goodness of Fit results show that the $\mathrm{f}$-square value is greater than 0.35 , the SMSR is 0.076 or less than 0.10 , and the NFI value is greater than 0.9 . As a result, it is possible to conclude that the model meets the criteria. $\mathrm{R}$ square in this model's inner analysis is 0.884 , and R Square Adjusted is 0.883 (brand engagement) and 0.658 and 0.655 , respectively, for self-brand connection. As a result, it is possible to conclude that the value of $\mathrm{R}$ square is greater than 0.5 , indicating the strength of the model's fit with the criteria, and that Adjusted R Square, indicating the ability of an exogenous construct to explain 
endogenous constructs. The results are also supported by the fulfilment of the inner model assumption, which requires the absence of multivariable, as indicated by a VIF value of less than 5 for each variable indicator.

Because the p-value is less than 0.05 (Table 3), the hypothesis testing results show that $\mathrm{H} 1, \mathrm{H} 2, \mathrm{H} 3, \mathrm{H} 4$, and $\mathrm{H} 5$ are accepted. These findings suggest that a gameful experience has a direct impact on the selfbrand connection. Additionally, the game design has a positive impact on the self-brand connection. Meanwhile, brand engagement mediates gameful experience and game design on the self-brand connection. This study supports previous research on the importance of fulfilling aspects of enjoyment, absorption, activation, creative thinking, and the absence of negative situations on the quality of experience obtained by e-commerce consumers. [18] [27] [28]. The quality of a pleasant experience, tailored to the consumers' perceived value and personality, can make them feel connected to and loyal to the brand.

Furthermore, game design on self-brand connection, which supports previous research about game design impact on consumer behaviour [5]. This demonstrates that mechanics (game rules), story (narrative), aesthetics (game environment), and technology all have an impact on consumers' self-brand connections [19] [15] [1].

The findings of the analysis on each indicator show that having clear rules in the game makes easier for consumers to understand how the game should be played, and they can achieve scores and level up with rewards in the form of points that they can use to get discounts on purchases. The story aspect also assist consumers in comprehending the advertisement ads that e-commerce wishes to convey through their gamification services. Consumers are also at ease with the aesthetic aspect (game environment), which features bright colours that match the colours of the ecommerce brand, eliciting brand recall, enthusiasm, and a pleasant feeling when using advergames. Interfaces, navigation, leader boards, buttons, and badges are also popular with customers because they demonstrate their performance. Brand engagement also effectively mediates gameful experience and game design correlation which supporting previous research that consumers' emotional and cognitive attachment to brands prior to using advergames influences gameful experience and game design on consumer behaviour. This emotional attachment is reflected in high customer awareness of e-commerce brands, whereas cognitive engagement is typically reflected in high consumer perceived benefits of e-commerce services manifested in frequent use of e-commerce services (frequent users) [68].

\section{CONCLUSION}

This study concludes that aspects of gameful experience, game design, and brand engagement mediation have a positive effect on self-brand connection, which is expected to have a positive influence on purchase intention. This is what motivates e-commerce platforms to improve the user experience through advertising games. Furthermore, the findings of this study provide input for UX designers in identifying and recommending experimental qualities to address when designing player-centered advergame design to support SMEs' resilience in the Covid-19 pandemic crisis. Furthermore, more research is needed to investigate the impact of gamification and game design on consumer behaviour when moderating variables such as monetary rewards, mandatory play, and time pressure are present.

\section{AUTHORS' CONTRIBUTIONS}

Ika Diyah Candra Arifah develops the conceptual framework, gathers, analyzes, and interprets data, and writes the manuscript.

\section{ACKNOWLEDGMENTS}

The author thanks Technology Management Department, ITS and Management Department, UNESA for supporting this study.

\section{REFERENCES}

[1] McKinsey, 2018. The digital archipelago: How online commerce is driving Indonesia's economic development. McKinsey \& Company. Retrieved from https://www.mckinsey.com/ /media/McKinsey/ Featured\%20Insights/Asia\%20Pacific/The\%20d igital\%20archipelago $\% 20$ How $\% 20$ online $\% 20 \mathrm{c}$ ommerce\%20is\%20driving\%20Indonesias \%20e conomic\%20development/FINAL_The-digitalarchipelago-How-online-commerce-is-drivingIndonesias-economic-development.ashx

[2] Niranjanamurthy, M., Kavyashree, N., Jagannath, S., \& Chahar, D, 2013. Analysis of ecommerce and m-commerce: advantages, limitations and security issues. International Journal of Advanced Research in Computer and Communication Engineering, 2(6), 2360-2370.

[3] McKinsey, 2016. Unlocking Indonesia's digital opportunity. McKinsey \& Company. Retrieved https://www.mckinsey.com/ /media/McKinsey/ Locations/Asia/Indonesia/Our\%20Insights/Unlo cking\%20Indonesias\%20digital\%20opportunity 
/Unlocking_Indonesias_digital_opportunity.ash X

[4] Chou, Y-K. 2015. Actionable Gamification Beyond Points, Badges, Leaderboards, Octalysis Media, Milpitas, CA (USA).

[5] Deterding, S., Dixon, D., Khaled, R. and Nacke, L., 2011. "From game design elements to gamefulness: defining 'gamification'”, Proceedings of the 15th International Academic MindTrek Conference: Envisioning Future Media Environments, (MindTrek '11), ACM, New York, NY, USA, pp. 9-15, DOI: 10.1145/2181037.2181040.

[6] Hsu, C.-L. and Chen, M.-C., 2018. How gamification marketing activities motivate desirable consumer behaviors: focusing on the role of brand love. Computers in Human Behavior, Vol. 88, pp. 121-133.

[7] Yang, Y., Asaad, Y. and Dwivedi, Y., 2017. "Examining the impact of gamification on intention of engagement and brand attitude in the marketing context", Computers in Human Behavior, Vol. 73, August, pp. 459-469.

[8] Siemens, J.C., Scott, S., Fisher, D., Thyroff, A. and Killian, G., 2015. "Level up! The role of progress feedback type for encouraging intrinsic motivation and positive brand attitudes in public versus private gaming contexts", Journal of Interactive Marketing, Vol. 32, November, pp. 112.

[9] Van Reijmersdal, E. A., Rozendaal, E., \& Buijzen, M., 2012. Effects of prominence, involvement, and persuasion knowledge on children's cognitive and affective responses to advergames. Journal of Interactive Marketing, 26(1), 33-42.

[10] Muller-Stewens, J., Tobias Schlager, Haubl, G. and Herrmann, A., 2017. "Gamified information presentation and consumer adoption of product innovations", Journal of Marketing, Vol. 81, March, pp. 8-24.

[11] Kim, K. and Ahn, S.J., 2017. "Rewards that undermine customer loyalty? A motivational approach to loyalty programs", Psychology and Marketing, Vol. 34, August, pp. 842-852.

[12] Hwang, J. and Choi, L., 2020. "Having fun while receiving rewards? Exploration of gamification in loyalty programs for consumer loyalty", Journal of Business Research, Vol. 106, January, pp.

$365-376$

DOI:

10.1016/j.jbusres.2019.01.031.

[13] Kitchen, P.J. and Kim, K., 2018. "The effects of gamified customer benefits and characteristics on behavioral engagement and purchase: evidence from mobile exercise application uses", Journal of Business Research, Vol. 92, pp. 250259.

[14] Iyer, E. S., 1989. Unplanned Purchasing: Knowledge of shopping environment and. Journal of retailing, 65(1), 40.

[15] Bauer, J. C., Linzmajer, M., Nagengast, L., Rudolph, T., \& D'Cruz, E., 2020. Gamifying the digital shopping experience: games without monetary participation incentives increase customer satisfaction and loyalty. Journal of Service Management.

[16] Wolf, T., Weiger, W.H. and Hammerschmidt, M. 2020, "Experiences that matter? The motivational experiences and business outcomes of gamified services", Journal of Business Research, Vol. 106 January, pp. 353-364, DOI: 10.1016/j.jbusres.2018.12.058.

[17] Eisingerich, A.B., Marchand, A., Fritze, M.P. and Dong, L. 2019, "Hook vs Hope: how to enhance customer engagement through gamification", International Journal of Research in Marketing, Vol. 36 No. 2, June, pp. 200-215, DOI: 10.1016/j.ijresmar.2019.02.003.

[18] Huotari, K. and Hamari, J., 2017, “A definition for gamification: anchoring gamification in the service marketing literature", Electronic Markets, Vol. 27 No. 1, pp. 21-31.

Hanus, M. D., \& Fox, J., 2015. Persuasive avatars: The effects of customizing a virtual salesperson's

[19] appearance on brand liking and purchase intentions. International Journal of HumanComputer Studies, 84, 33-40.

[20] Poncin, I., Garnier, M., Mimoun, M. S. B., \& Leclercq, T., 2017. Smart technologies and shopping experience: Are gamification interfaces effective? The case of the Smartstore. Technological Forecasting and Social Change, 124, 320-331.

[21] Bidler, M., Zimmermann, J., Schumann, J. H., \& Widjaja, T., 2020. Increasing Consumers' Willingness to Engage in Data Disclosure Processes through Relevance-Illustrating Game Elements. Journal of Retailing, 96(4), 507-523.

[22] Kaiser, I., Jensen, K., Call, J., \& Tomasello, M., 2012. Theft in an ultimatum game: Chimpanzees 
and bonobos are insensitive to unfairness. Biology Letters, 8(6), 942-945.

[23] Poels, K., De Kort, Y., \& Ijsselsteijn, W., 2007. " It is always a lot of fun!" exploring dimensions of digital game experience using focus group methodology. In Proceedings of the 2007 conference on Future Play (pp. 83-89).

[24] Juul, J., 2010. A casual revolution: Reinventing video games and their players. MIT press.

[25] Landers, R. N., Tondello, G. F., Kappen, D. L., Collmus, A. B., Mekler, E. D., \& Nacke, L. E., 2019. Defining gameful experience as a psychological state caused by gameplay: Replacing the term 'Gamefulness' with three distinct constructs. International Journal of Human-Computer Studies, 127, 81-94.

[26] Vassileva, J., 2012. Motivating participation in social computing applications: a user modeling perspective. User Modeling and User-Adapted Interaction, 22(1), 177-201.

[27] Seaborn, K. and Fels, D.I., 2015. "Gamification in theory and action: a survey", International Journal of Human-Computer Studies, Vol. 74, February, pp. 14-31.

[28] Werbach, K., 2014. (Re)defining gamification: A process approach. In: Spagnolli, A., Chittaro, L., Gamberini, L. (eds.) Persuasive Technology, PERSUASIVE 2014. Lecture Notes in Computer Science 2014, pp. 266-272. Springer, Cham (2014)

[29] Deterding, S., Dixon, D., Khaled, R. and Nacke, L., 2011. "From game design elements to gamefulness: defining 'gamification'", Proceedings of the 15th International Academic MindTrek Conference: Envisioning Future Media Environments, (MindTrek '11), ACM, New York, NY, USA, pp. 9-15, DOI: $10.1145 / 2181037.2181040$.

[30] Bauer, J.C., Schmitt, P., Morwitz, V.G. and Winer, R.S., 2013. "Managerial decision making in customer management: adaptive, fast, and frugal?", Journal of the Academy of Marketing Science, Vol. 41 No. 4, pp. 436-455.

[31] Berger, A., Schlager, T., Sprott, D.E. and Herrmann, A., 2018. "Gamified interactions: whether, when, and how games facilitate selfbrand connections", Journal of the Academy of Marketing Science, Vol. 46, pp. 652-673.

[32] Whitton, N., 2009. Learning with digital games: A practical guide to engaging students in higher education. Routledge.
[33] Afshar, R., Banerjee, D., \& Jones, C., 2004. Advergaming Developer's Guide: Using Macromedia Flash MX 2004 and Macromedia Director MX. Charles River Media, Inc.

[34] Mishra, S., \& Malhotra, G., 2020. The gamification of in-game advertising: Examining the role of psychological ownership and advertisement intrusiveness. International Journal of Information Management, 102245.

[35] Tina, W., \& Buckner, K., 2006. Receptiveness of gamers to embedded brand messages in advergames: Attitudes towards product placement. Journal of interactive advertising, 7(1), 3-32.

[36] Speck, P. S., \& Elliott, M. T.,1997. Predictors of advertising avoidance in print and broadcast media. Journal of Advertising, 26(3), 61-76.

[37] Benway, J. P., 1999. Banner blindness: What searching users notice and do not notice on the World Wide Web. Rice University.

[38] Ducoffe, R. H., 1996. Advertising value and advertising on the web. Journal of advertising research, 36(5), 21-21.

[39] Bittner, J. V., \& Zondervan, R., 2015. Motivating and achievement-eliciting pop-ups in online environments: A user experience perspective. Computers in Human Behavior, 50 , 449-455.

[40] Lee, E., Kim, Y. J., Lim, Y. S., \& Kim, M., 2015 Trait reactance moderates Facebook users irritation with brand communication. Social Behavior and Personality: an international journal, 43(5), 829-844.

[41] Högberg, J., Ramberg, M. O., Gustafsson, A., \& Wästlund, E., 2019. Creating brand engagement through in-store gamified customer experiences. Journal of Retailing and Consumer Services, 50, 122-130.

[42] Eppmann, R., Bekk, M. and Klein, K., 2018 "Gameful experience in gamification: construction and validation of a gameful experience scale (GAMEX)", Journal of Interactive Marketing, Vol. 43, August, pp. 98-115.

[43] Mekler, E. D., Bopp, J. A., Tuch, A. N., \& Opwis, K., 2014. A systematic review of quantitative studies on the enjoyment of digital entertainment games. In Proceedings of the SIGCHI conference on human factors in computing systems (pp. $927-$ 936).

[44] Sweetser, P., Wyeth, P., 2005. GameFlow: a model for evaluating player enjoyment in games. Comput. Entertain. 3(3), 1-24.

[45] Poels, K., De Kort, Y., Ijsselsteijn, W., 2007. "It is ways a lot of fun!" Exploring dimensions of digital tme experience using focus group methodology. In: 
oceedings of the 2007 Conference on Future Play, Itureplay 2007, Controlling order-effect bias. oronto, ON, Canada.

[46] Brockmeyer, J.H., Fox, C.M., Curtiss, K.A., McBroom, E., Burkhart, K.M. and Pidruzny, J.N., 2009. "The development of the game engagement questionnaire: a measure of engagement in video gameplaying", Journal of Experimental Social Psychology, Vol. 45 No. 4, pp. 624-634.

[47] Csikszentmihalyi, M. and Nakamura, J., 2010. "Effortless attention in everyday life: a systematic phenomenology", in Bruya, B. (Ed.), Effortless Attention: A New Perspective in the Cognitive Science of Attention and Action, MIT Press, Cambridge, MA, pp. 179-189.

[48] Hamat, L., de Manzano, O., Theorell, T., Hogman, L., Fischer, H. and Ullen, F., 2015. "Physiological correlates of the flow experience during computer game playing", International Journal of Psychophysiology, Vol. 97 No. 1, pp. 1-7.

[49] Cairns, P., Cox, A., \& Nordin, A. I., 2014 Immersion in digital games: review of gaming experience research. Handbook of digital games, 1,767 .

[50] Qin, H., Patrick Rau, P. L., \& Salvendy, G., 2009. Measuring player immersion in the computer game narrative. Intl. Journal of Human-Computer Interaction, 25(2), 107-133.

[51] Lee, D., Conroy, M. L., McGreevy, B. P., \& Barraclough, D. J., 2004. Reinforcement learning and decision making in monkeys during a competitive game. Cognitive brain research, 22(1), 45-58.

[52] Korhonen, H., Montola, M., \& Arrasvuori, J., 2009. Understanding playful user experience through digital games. In International Conference on Designing Pleasurable Products and Interfaces (Vol. 2009).

[53] Ermi, L., \& Mäyrä, F., 2005. Player-centred game design: Experiences in using scenario study to inform mobile game design. Game Studies, 5(1), 1-10.

[54] Steffen, C., Mau, G., \& Schramm-Klein, H., 2013. Who is the loser when I lose the game? Does losing an advergame have a negative impact on the perception of the brand?. Journal of Advertising, 42(2-3), 183-195.

[55] Cosmides, L., \& Tooby, J., 2000. Evolutionary psychology and the emotions. Handbook of emotions, 2(2), 91-115.

[56] Schell, J., 2008. The Art of Game Design: A book of lenses. CRC press.
[57] Green, M. C., Brock, T. C., \& Kaufman, G. F., 2004. Understanding media enjoyment: The role of transportation into narrative worlds. Communication theory, 14(4), 311-327.

[58] Van Laer, T., De Ruyter, K., Visconti, L. M., \& Wetzels, M., 2014. The extended transportationimagery model: A meta-analysis of the antecedents and consequences of consumers' narrative transportation. Journal of Consumer research, 40(5), 797-817.

[59] Arriavabene, Rafael., 2017. The Language of Interaction. Transmission: The Journal of Film and Media Studies, Vol.2 (2), pp. 17-29.

[60] Calder, B. J., Malthouse, E. C., \& Schaedel, U., 2009. An experimental study of the relationship between online engagement and advertising effectiveness. Journal of interactive marketing, 23(4), 321-331.

[61] Hollebeek, L. 2011, Exploring customer brand engagement: definition and themes. Journal of Strategic Marketing, 19(7), 555-573.

[62] Moneta, G. B., Schneider, B., \& Csikszentmihalyi, M., 2017. A longitudinal study of the self-concept and experiential components of self-worth and affect across adolescence. In Applied Developmental Science (pp. 125-142). Psychology Press.

[63] Van Noort, G., Voorveld, H. A., \& Van Reijmersdal, E. A., 2012. Interactivity in brand web sites: cognitive, affective, and behavioral responses explained by consumers' online flow experience. Journal of Interactive Marketing, 26(4), 223-234.

[64] Koufaris, M., 2002. Applying the technology acceptance model and flow theory to online consumer behavior. Information systems research, 13(2), 205-223.

[65] Chua, P. H., Jung, Y., Lwin, M. O., \& Theng, Y. L., 2013. Let's play together: Effects of videogame play on intergenerational perceptions among youth and elderly participants. Computers in Human Behavior, 29(6), 2303-2311

[66] Abuhamdeh, S., \& Csikszentmihalyi, M., 2012. Attentional involvement and intrinsic motivation. Motivation and Emotion, 36(3), $257-$ 267.

[67] Schneider, L. P., Systems, B., \& Cornwell, T. B., 2005. Cashing in on crashes via brand placement in computer games: The effects of experience and 
flow on memory. International Journal of Advertising, 24(3), 321-343.

[68] Hollebeek, L., 2011. Exploring customer brand engagement: definition and themes. Journal of Strategic Marketing, 19(7), 555-573.

[69] Batra, R., Ahuvia, A., \& Bagozzi, R. P., 2012. Brand love. Journal of marketing, 76(2), 1-16.

[70] Patra, R., Pal, J., Nedevschi, S., Plauche, M., \& Pawar, U., 2007. Usage models of classroom computing in developing regions. In 2007 International Conference on Information and Communication Technologies and Development (pp. 1-10). IEEE.

[70] Patra, R., Pal, J., Nedevschi, S., Plauche, M., \& Pawar, U., 2007. Usage models of classroom computing in developing regions. In 2007 International Conference on Information and Communication Technologies and Development (pp. 1-10). IEEE.

[71] Sarstedt, M., Ringle, C. M., \& Hair, J. F, 2017. Partial least squares structural equation modeling. Handbook of market research, 26(1), 140 .

[72] Wong, K. K. K. (2013). Partial least squares structural equation modeling (PLS-SEM) techniques using SmartPLS. Marketing Bulletin, 24(1), 1-32.

[73] Cangur, S., \& Ercan, I. (2015). Comparison of model fit indices used in structural equation modeling under multivariate normality. Journal of Modern Applied Statistical Methods, 14(1), 14. 